Article

\title{
Compatibility of 3D-Printed Oxide Ceramics with Molten Chloride Salts for High-Temperature Thermal Energy Storage in Next-Generation CSP Plants
}

\author{
Wenjin Ding ${ }^{1, *(\mathbb{D})}$, Yuan Shi ${ }^{2, *(\mathbb{D}}$, Markus Braun ${ }^{1}$, Fiona Kessel ${ }^{2}$, Martin Frieß ${ }^{2}$, Alexander Bonk ${ }^{1}(\mathbb{D})$ and $^{2}$ \\ Thomas Bauer ${ }^{3}$ (D) \\ 1 Institute of Engineering Thermodynamics, German Aerospace Center (DLR), 70569 Stuttgart, Germany; \\ Mar.Braun@dlr.de (M.B.); alexander.bonk@dlr.de (A.B.) \\ 2 Institute of Structures and Design, German Aerospace Center (DLR), 70569 Stuttgart, Germany; \\ Fiona.Kessel@dlr.de (F.K.); Martin.Friess@dlr.de (M.F.) \\ 3 Institute of Engineering Thermodynamics, German Aerospace Center (DLR), 51147 Cologne, Germany; \\ thomas.bauer@dlr.de \\ * Correspondence: wenjin.ding@dlr.de (W.D.); yuan.shi@dlr.de (Y.S.)
}

Citation: Ding, W.; Shi, Y.; Braun, M.; Kessel, F.; Frieß, M.; Bonk, A.; Bauer, T. Compatibility of 3D-Printed Oxide Ceramics with Molten Chloride Salts for High-Temperature Thermal Energy Storage in Next-Generation CSP Plants. Energies 2021, 14, 2599. https://doi.org/10.3390/en14092599

Academic Editor: Massimo Viviani

Received: 29 March 2021

Accepted: 28 April 2021

Published: 1 May 2021

Publisher's Note: MDPI stays neutral with regard to jurisdictional claims in published maps and institutional affiliations.

Copyright: (c) 2021 by the authors. Licensee MDPI, Basel, Switzerland. This article is an open access article distributed under the terms and conditions of the Creative Commons Attribution (CC BY) license (https:// creativecommons.org/licenses/by/ $4.0 /)$.

\begin{abstract}
Oxide ceramics could be attractive high-temperature construction materials for critical structural parts in high-temperature molten salt thermal energy storage systems due to their excellent corrosion resistance and good mechanical properties. The 3D-printing technology allows the production of ceramic components with highly complex geometries, and therefore extends their applications. In this work, 3D-printed $\mathrm{ZrO}_{2}$ and $\mathrm{Al}_{2} \mathrm{O}_{3}$ ceramics were immersed in molten $\mathrm{MgCl}_{2} / \mathrm{KCl} / \mathrm{NaCl}$ under argon or exposed in argon without molten chlorides at $700{ }^{\circ} \mathrm{C}$ for $600 \mathrm{~h}$. Their material properties and microstructure were investigated through three-point-bend (3PB) testing and material analysis with SEM-EDX and XRD. The results show that the 3D-printed $\mathrm{Al}_{2} \mathrm{O}_{3}$ maintained its mechanical property after exposure in the strongly corrosive molten chloride salt. The $3 \mathrm{D}$-printed $\mathrm{ZrO}_{2}$ had an enhanced 3PB strength after molten salt exposure, whereas no change was observed after exposure in argon at $700{ }^{\circ} \mathrm{C}$. The material analysis shows that some of the $\mathrm{ZrO}_{2}$ on the sample surface changed its crystal structure and shape $(\mathrm{T} \rightarrow \mathrm{M}$ phase transformation) after molten salt exposure, which could be the reason for the enhanced $3 \mathrm{~PB}$ strength. The thermodynamic calculation shows that the $\mathrm{T} \rightarrow \mathrm{M}$ transformation could be caused by the reaction of the $\mathrm{Y}_{2} \mathrm{O}_{3}$-stabilized $\mathrm{ZrO}_{2}$ with $\mathrm{MgCl}_{2}$ (mainly $\mathrm{Y}_{2} \mathrm{O}_{3}$ and $\mathrm{ZrO}_{2}$ with gaseous $\mathrm{MgCl}_{2}$ ). In conclusion, the $3 \mathrm{D}$-printed $\mathrm{ZrO}_{2}$ and $\mathrm{Al}_{2} \mathrm{O}_{3}$ ceramics have excellent compatibility with corrosive molten chlorides at high temperatures and thus show a sound application potential as construction materials for molten chlorides.
\end{abstract}

Keywords: concentrated solar power (CSP); 3D-printed $\mathrm{ZrO}_{2}$ and $\mathrm{Al}_{2} \mathrm{O}_{3}$ ceramics; three-point-bend strength (3PB strength); corrosion resistance; molten salt

\section{Introduction}

Molten chlorides are promising next-generation high-temperature (up to $800{ }^{\circ} \mathrm{C}$ ) thermal energy storage (TES) and heat transfer fluid (HTF) materials in, for example, nextgeneration concentrated solar power (CSP) plants [1]. However, one of the main challenges in industrial applications is that molten chlorides are very corrosive to conventional metallic construction materials such as commercial Cr-Fe-Ni alloys at high temperatures [1-5]. It was reported that even the Ni-based superalloys like Hastelloy (cost $>\$ 20$ per $\mathrm{kg}$ ) cannot meet the requirements of corrosion resistance in commercial applications (corrosion rate $<10 \mu \mathrm{m} /$ year for 30 year lifetime) when they contact with molten chlorides at high temperatures under inert atmosphere (e.g., $\mathrm{MgCl}_{2} / \mathrm{NaCl} / \mathrm{KCl}$ at $700{ }^{\circ} \mathrm{C}$ ) [3-7].

Oxide ceramics like $\mathrm{Al}_{2} \mathrm{O}_{3}$ and $\mathrm{ZrO}_{2}$ are attractive construction materials for hightemperature applications such as in the field of conventional power generation [8] and 
molten salt TES/HTF technology [9] due to their excellent corrosion resistance, good mechanical strength at high temperatures and low material costs. The ceramics generally have a better chemical compatibility with corrosive media like molten salts than metallic materials [10]. Yttria-stabilized zirconia (YSZ) ceramic coatings on alloys have demonstrated resistance to the hot corrosion of molten chlorides like $\mathrm{LiCl}-\mathrm{KCl}$ at high temperatures [11,12]. For instance, Jagadeeswara Rao et al. showed that 8-9 wt.\% yttria-stabilized zirconia (YSZ) ceramic coating on an alloy was corrosion resistant to molten $\mathrm{LiCl}-\mathrm{KCl}-\mathrm{UCl}_{3}(5-6 \mathrm{wt} . \%)$ salt at $600{ }^{\circ} \mathrm{C}$ under argon atmosphere in a $2000 \mathrm{~h}$ molten salt exposure test [11]. Thus, the oxide ceramics are often used for molten chloride laboratory experiments (e.g., corrosion, electrochemistry, crucibles) $[10,13]$. Furthermore, they could be attractive high-temperature construction materials for critical structural parts in contact with strongly corrosive molten salts (e.g., moving parts such as pump bearings [14], seals, electrical insulators and hot surfaces). Recently, X. He et al. reported the use of $\mathrm{ZrO}_{2}$ as a bearing material in molten chloride pumps for next-generation CSP plants [14].

However, compared to metallic alloys, they have much weaker toughness and lower resistance to, for example, thermal shock. Moreover, their extreme hardness and brittleness lead to extremely difficult machining of ceramic components and thus limit their applications [15]. One way to improve the applicability of ceramics is via ceramic composites technology [16]. Compared to ceramics, ceramic composites have much better fracture toughness because of their composite structure, leading to easier machining [16]. In our previous work [16], we confirmed the excellent corrosion resistance of a carbon-fiber-reinforced silicon carbide composite $\left(\mathrm{C} / \mathrm{C}-\mathrm{SiC}\right.$ composite) in molten chlorides $\left(\mathrm{MgCl}_{2} / \mathrm{NaCl} / \mathrm{KCl}\right.$ $60 / 20 / 20 \mathrm{~mole} \%$ ) under argon atmosphere via immersion test at $700{ }^{\circ} \mathrm{C}$ for $500 \mathrm{~h}$. Besides ceramic composites, the introduction of 3D printing, also referred to as additive manufacturing (AM), into the manufacturing of ceramic components offers new possibilities for addressing the aforementioned challenges, and extends their applications [15]. For instance, 3D-printed oxide ceramic components with highly complex geometries [15,17], such as high-performance ceramic heat exchangers [17] and sample holders used in our other works for molten salt corrosion tests (see Figure 1) have become available. Moreover, compared to ceramic composites, the 3D-printed oxide ceramics like $\mathrm{ZrO}_{2}$ can have much lower porosity $(<1 \%$, see Section 2.1$)$, which is critically required in the construction materials of, for example, molten salt heat exchangers. However, it is well known that different production processes (conventional or 3D printing) for materials such as alloys [18] can lead to different microstructures and properties, including anti-corrosion properties. To our best knowledge, no open literature is available on corrosion resistance and the application of 3D-printed oxide ceramics in high-temperature TES/HTF or other applications using molten chloride salts.

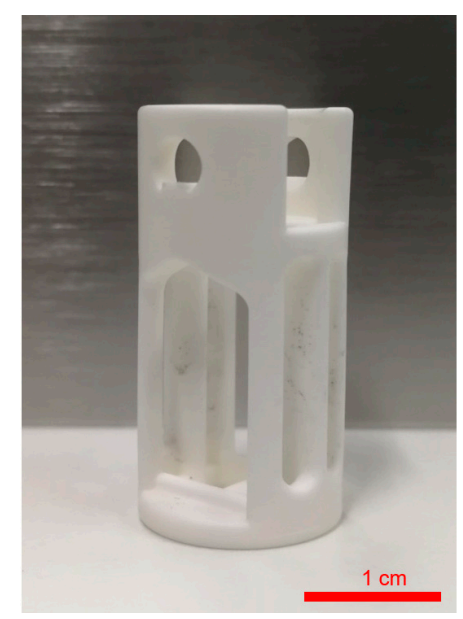

Figure 1. An example of a 3D-printed ceramic component: sintered alumina sample holder, which is used in our other works for molten chloride corrosion tests. 
In this work, the compatibility of $3 \mathrm{D}$-printed $\mathrm{ZrO}_{2}$ and $\mathrm{Al}_{2} \mathrm{O}_{3}$ ceramics with molten chlorides is investigated. The as-received 3D-printed ceramics are immersed in molten $\mathrm{MgCl}_{2} / \mathrm{NaCl} / \mathrm{KCl}(60 / 20 / 20 \mathrm{~mole} \%)$ at $700{ }^{\circ} \mathrm{C}$ for $600 \mathrm{~h}$ under argon atmosphere to study their corrosion resistance in contact with the strongly corrosive molten chloride salt. Moreover, they are exposed in argon atmosphere at $700{ }^{\circ} \mathrm{C}$ for $600 \mathrm{~h}$ to investigate the effect of a pure thermal treatment without molten salt. The material properties and microstructures of all the 3D-printed ceramics are investigated through 3PB mechanical testing and additional analysis with scanning electron microscopy (SEM), energy dispersive $X$-ray (EDX) scanning and X-ray diffraction (XRD). The effect of the molten salt exposure on the 3D-printed $\mathrm{ZrO}_{2}$ and $\mathrm{Al}_{2} \mathrm{O}_{3}$ ceramics is discussed based on the tests and analysis, in order to determine if they can be used as construction materials in contact with strongly corrosive molten chloride salts.

\section{Experimental}

\subsection{Chemicals and $3 D$-Printed Ceramics}

$\mathrm{KCl}$ (Alfa Aesar, Munich, Germany, >99 wt.\%), NaCl (Alfa Aesar, Germany, >99 wt.\%) and anhydrous $\mathrm{MgCl}_{2}$ (Magnesia, Lüneburg, Germany, >99 wt.\%, technical grade) were used to synthesize the salt mixture of $\mathrm{MgCl}_{2} / \mathrm{KCl} / \mathrm{NaCl}(60 / 20 / 20$ mole $\%)$ for immersion tests. The 3D-printed specimens were provided by Steinbach AG, Germany, with $99.8 \%$ purity, $1.6 \%$ porosity and $98.4 \%$ of its theoretical density $\left(3.985 \mathrm{~g} / \mathrm{cm}^{3}\right)$ for $\mathrm{Al}_{2} \mathrm{O}_{3}$ and $99.9 \%$ purity, $0.6 \%$ porosity and $99.8 \%$ of its theoretical density $\left(6.088 \mathrm{~g} / \mathrm{cm}^{3}\right)$ for $\mathrm{ZrO}_{2}$ [19]. The $\mathrm{ZrO}_{2}$ was stabilized with 3 mole $\% \mathrm{Y}_{2} \mathrm{O}_{3}$. All specimens were produced by Lithographybased Ceramic Manufacturing (LCM) [17] on a CeraFab-system from Lithoz (Vienna, Austria) using LithaLox 350 for $\mathrm{Al}_{2} \mathrm{O}_{3}$ and LithaCon $3 Y 230 \mathrm{D}$ for $\mathrm{ZrO}_{2}$. In the printing, a slurry of ceramic particles and photo-active polymer was exposed layer by layer to form the 3-dimentional part. After exposure, the residual not-polymerized slurry was cleaned, then the polymer phase in the green body was released by tempering $\left(\mathrm{Al}_{2} \mathrm{O}_{3}\right.$ : $134 \mathrm{~h}$ preconditioning up to $120^{\circ} \mathrm{C}$ and $102 \mathrm{~h}$ debinding up to $1100{ }^{\circ} \mathrm{C} ; \mathrm{ZrO}_{2}: 134 \mathrm{~h}$ preconditioning up to $120{ }^{\circ} \mathrm{C}$ and $58 \mathrm{~h}$ debinding up to $600{ }^{\circ} \mathrm{C}$ ) followed by sintering $\left(\mathrm{Al}_{2} \mathrm{O}_{3}: 48 \mathrm{~h}\right.$ up to $1600{ }^{\circ} \mathrm{C} ; \mathrm{ZrO}_{2}: 28 \mathrm{~h}$ up to $\left.1450{ }^{\circ} \mathrm{C}\right)$ to the final product.

\subsection{High-Temperature Tests}

Figure 2 shows a schematic of the experimental set-up used for high-temperature tests on the 3D-printed oxide ceramics. Two tests were conducted: (1) immersion test in molten salt under Ar atmosphere at $700{ }^{\circ} \mathrm{C}$ for $600 \mathrm{~h}$, and (2) exposure test in Ar gas without molten salt at $700{ }^{\circ} \mathrm{C}$ for $600 \mathrm{~h}$.

In Test 1 , a high-temperature-resistant glassy carbon crucible (Sigradur ${ }^{\circledR}$ G, GAZ 4) purchased from HTW, Germany was used to avoid any reaction of the molten salts with the crucible. The temperature of the molten salt under argon atmosphere at $700{ }^{\circ} \mathrm{C}$ was controlled by a thermocouple close to the crucible. Referring to previous work [16], the heating of the salts were conducted as follows: after four times vacuumization ( $\leq 50 \mathrm{mbar})$, the salt mixture was heated to $\sim 200{ }^{\circ} \mathrm{C}$ and kept under argon atmosphere (purity $\geq 99.999 \%$, $\mathrm{H}_{2} \mathrm{O} \leq 0.5 \mathrm{ppm}, 40 \mathrm{~L} / \mathrm{h}(\mathrm{STP})$, the absolute pressure above the salts was $\sim 1.1 \mathrm{bar}$ ) for $1 \mathrm{~h}$ to remove residual water in the hygroscopic $\mathrm{MgCl}_{2}$ salt. After that, it was heated to $700{ }^{\circ} \mathrm{C}$ and kept at this temperature for corrosion tests with the immersed specimens of the 3D-printed $\mathrm{ZrO}_{2}$ and $\mathrm{Al}_{2} \mathrm{O}_{3}$ ceramics. As shown in Figure 2, the $3 \mathrm{D}$-printed $\mathrm{ZrO}_{2}$ and $\mathrm{Al}_{2} \mathrm{O}_{3}$ ceramics (three pieces for each, size: $45 \mathrm{~mm} \times 4 \mathrm{~mm} \times 3 \mathrm{~mm}$ ) were completely immersed in the molten $\mathrm{MgCl}_{2} / \mathrm{NaCl} / \mathrm{KCl}(60 / 20 / 20$ mole $\%, 10 \mathrm{~g})$. After $600 \mathrm{~h}$ exposure, the furnace was cooled down to room temperature under argon atmosphere. The specimens were washed with deionized water and dried. The corrosion resistance of the specimens was analyzed via mechanical tests and microstructural analysis.

In Test 2, the heating process was identical to Test 1 , but no molten salt was used. The 3D-printed $\mathrm{ZrO}_{2}$ and $\mathrm{Al}_{2} \mathrm{O}_{3}$ ceramics (three pieces for each, size: $45 \mathrm{~mm} \times 4 \mathrm{~mm} \times 3 \mathrm{~mm}$ ) 
were exposed in Ar gas at $700{ }^{\circ} \mathrm{C}$ for $600 \mathrm{~h}$. The effect of the pure thermal treatment on the $3 \mathrm{D}$-printed ceramics was analyzed via the $3 \mathrm{~PB}$ mechanical tests and microstructural analysis.

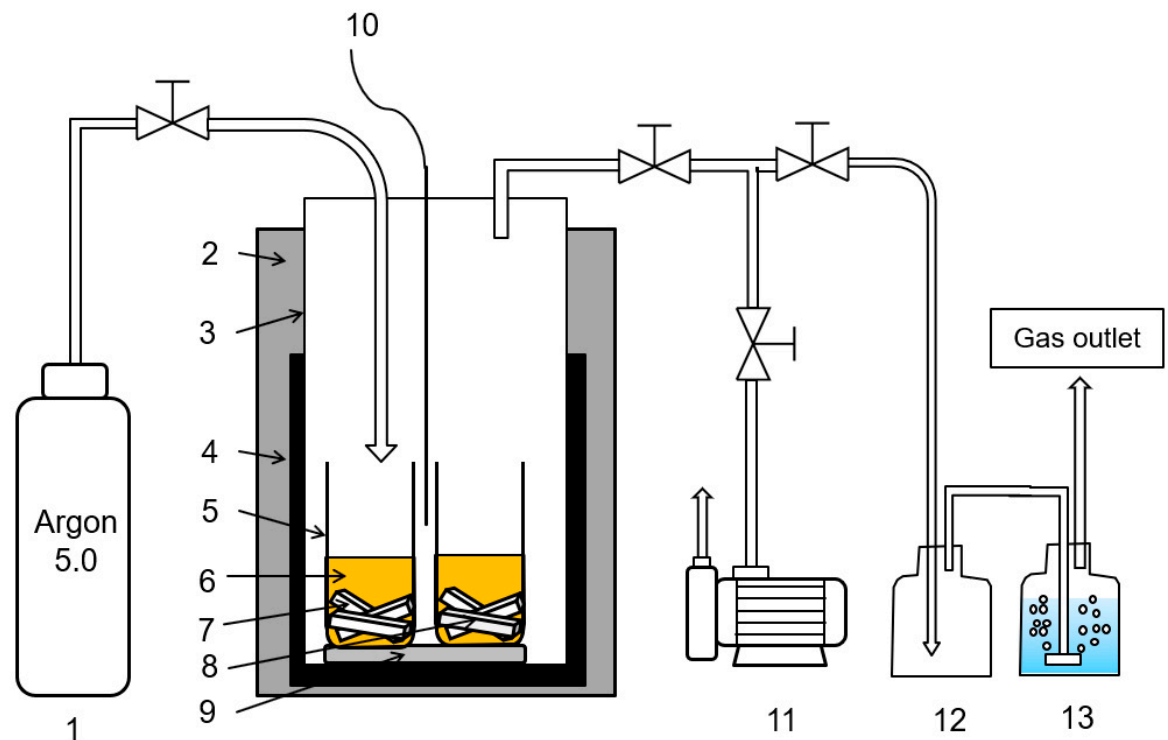

Figure 2. Schematic diagram of the experimental set-up for high-temperature static exposure tests. 1: Gas bottle for argon 5.0 gas, 2: glass wool heat isolator, 3: steel tubing of Incoloy 800 H, 4: furnace, 5: glassy carbon crucible, 6: molten chloride salt (Test 1) or Ar gas (Test 2), 7: coupons of 3D-printed $\mathrm{ZrO}_{2}$ ceramics, 8: coupons of 3D-printed $\mathrm{Al}_{2} \mathrm{O}_{3}$ ceramics, 9: $\mathrm{Al}_{2} \mathrm{O}_{3}$ plate, 10: thermocouple close to the molten salt, 11: vacuum pump, 12: security bottle (empty) to prevent reflux from the gas washing bottle, 13: bottle with $\mathrm{NaOH}$ solution for gas washing (removal of $\mathrm{HCl}$ and $\mathrm{Cl}_{2}$ ).

\subsection{Corrosion and Mechanical Analysis}

\subsubsection{Mechanical Tests}

The mechanical properties of the as-received coupons in the unexposed state $(\mathrm{G})$, after exposure in the molten chloride salt (AS) and after thermal treatment without molten chloride salt (AT) were determined and evaluated using 3-point bending (3PB) test according to DIN EN 843-1 [20]. Some more information on the mechanical tests can be found in our previous work on ceramic composites [16]. All the experiments were performed up to sample failure on a universal testing machine (Zwick 1494) at a controlled cross-head speed of $1 \mathrm{~mm} / \mathrm{min}$. The failure stress was calculated from the maximum load. For statistical confirmation, three samples for each ceramic type in each test with size $45 \mathrm{~mm} \times 4 \mathrm{~mm} \times 3 \mathrm{~mm}$ were tested.

\subsubsection{Material Analysis}

The microstructures were investigated using a scanning electron microscope (Zeiss Ultra Plus, Carl Zeiss Microscopy GmbH, Jena, Germany) and EDX (X-Max20, Oxford Instruments, Germany). Phase analysis was performed by X-ray diffraction (XRD) using a 20-goniometer (D8 Advance, Bruker AXS, Karlsruhe, Germany) with $\mathrm{Cu} \mathrm{K} \alpha$ radiation $(154.060 \mathrm{pm})$ with a step size of $0.05^{\circ}$ and $10 \mathrm{~s}$ time/step in the range of $10^{\circ}<2 \theta<90^{\circ}$.

\section{Results and Discussion}

\subsection{Mechanical Tests}

The measured 3PB strength values are summarized in Figure 3. The index G denotes the unexposed state, AS after exposure in the molten chloride salt and AT after thermal treatment without molten chloride salt. The measured value for as-received $\mathrm{Al}_{2} \mathrm{O}_{3}$ agrees well with the value of $395 \mathrm{MPa}$ in the data overview from Lithoz [19]. The results show that the 3D-printed $\mathrm{Al}_{2} \mathrm{O}_{3}$ maintained its mechanical property after exposure in the strongly 
corrosive molten $\mathrm{MgCl}_{2} / \mathrm{NaCl} / \mathrm{KCl}$ salt and Ar gas. This agrees with the findings in our previous work [21] and the work of J. Vidal et al. [22], who found that the $\mathrm{Al}_{2} \mathrm{O}_{3}$ coating was corrosion resistant in the molten chloride salts. Moreover, there was no significant difference in the strength values after pure thermal treatment. The 3D-printed $\mathrm{ZrO}_{2}$ had enhanced mechanical properties after exposure in the strongly corrosive molten chloride salt. The 3PB strength increased by $\sim 80 \%$. After exposure in the hot Ar gas at $700{ }^{\circ} \mathrm{C}$ for $600 \mathrm{~h}$, the 3PB strength of the 3D-printed $\mathrm{ZrO}_{2}$ had no significant change compared to the samples as received. This means the strength enhancement of the $3 \mathrm{D}$-printed $\mathrm{ZrO}_{2}$ was caused not (at least not mainly) by the heating, but by the exposure in the molten salt. The possible reasons for this will be discussed based on SEM, EDX and XRD analysis in Section 3.2.

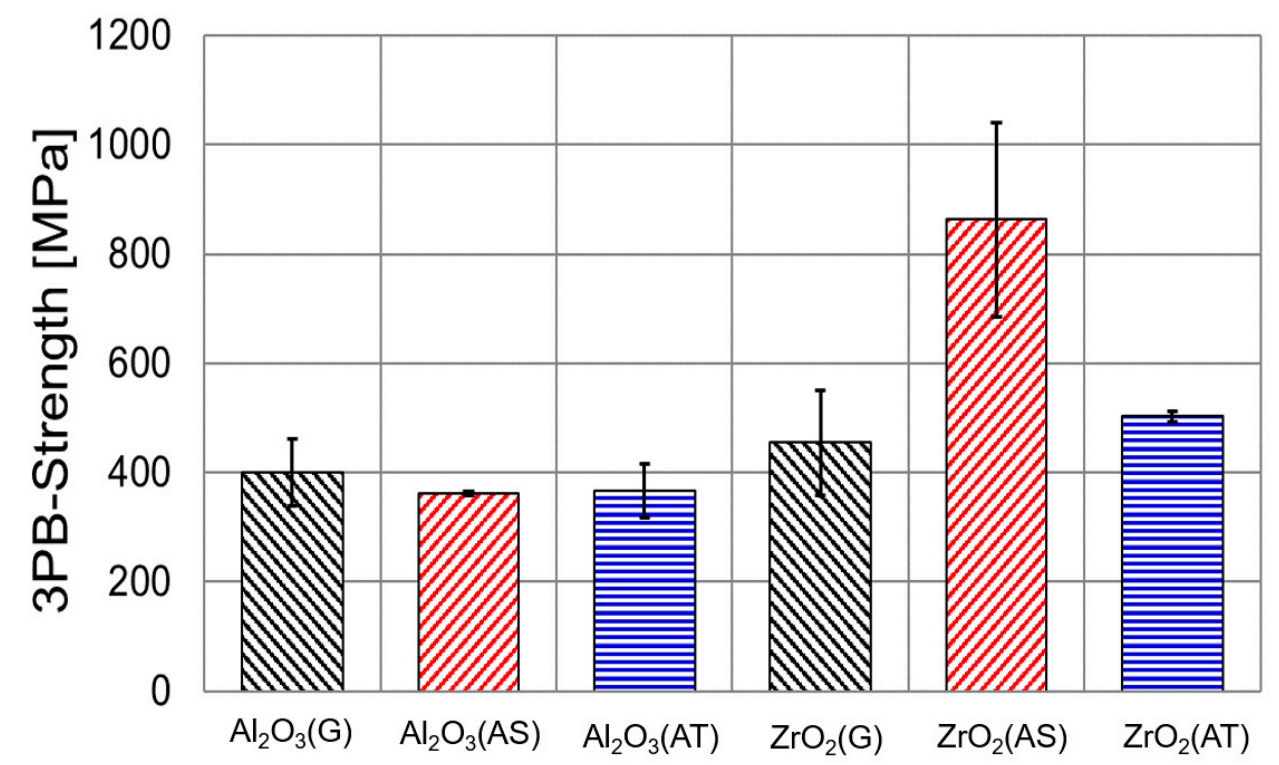

Figure 3. 3PB strength values of $\mathrm{Al}_{2} \mathrm{O}_{3}$ and $\mathrm{ZrO}_{2}$ in the unexposed state ( $\mathrm{G}$, black color), after exposure in the molten chloride salt (AS, red color) and after pure thermal treatment without molten chloride salt (AT, blue color).

\subsection{Material Analysis}

The microstructural analysis of the $\mathrm{Al}_{2} \mathrm{O}_{3}$ and $\mathrm{ZrO}_{2}$ samples was performed via XRD and SEM-EDX. Since no changes were detected for the 3D-printed $\mathrm{Al}_{2} \mathrm{O}_{3}$ in either the $3 \mathrm{~PB}$ strength or the microstructure and crystalline phase, only the results of the microstructural analysis on the 3D-printed $\mathrm{ZrO}_{2}$ are shown in this work to assess the enhancement of the 3D-printed $\mathrm{ZrO}_{2}$.

\subsubsection{XRD Analysis}

As shown in Figure 4, XRD analysis of the as-received and $\mathrm{Ar}$-annealed $\mathrm{ZrO}_{2}$ samples stabilized with 3 mole $\% \mathrm{Y}_{2} \mathrm{O}_{3}$ revealed the tetragonal phase (tazheranite $\mathrm{ZrO}_{2}$, theoretical density of $6.10 \mathrm{~g} / \mathrm{cm}^{3}$ [23]) as the main component, and other phases were not observed. This result agrees with the fact that the measured density of the sample by the supplier shown in [19] $\left(6.08 \mathrm{~g} / \mathrm{cm}^{3}\right)$ is very close to the theoretical density of the tazheranite $\mathrm{ZrO}_{2}$. When the sample was exposed in the molten $\mathrm{MgCl}_{2} / \mathrm{NaCl} / \mathrm{KCl}(60 / 20 / 20$ mole\%) salt under argon atmosphere at $700{ }^{\circ} \mathrm{C}$ for $600 \mathrm{~h}$, an additional monoclinic phase (baddeleyite $\mathrm{ZrO}_{2}$, theoretical density of $5.68 \mathrm{~g} / \mathrm{cm}^{3}$ [23]) was observed, clearly indicating that the phase change from tetragonal to monoclinic phase occurred. It is well known that the $\mathrm{T} \rightarrow \mathrm{M}$ phase transformation is associated with a volume expansion of 3-5\% (i.e., a decrease of the density) and could be beneficial in improving both the toughness and strength of the stabilized $\mathrm{ZrO}_{2}$ [24]. Thus, this can explain the 3PB strength enhancement of the sample. 


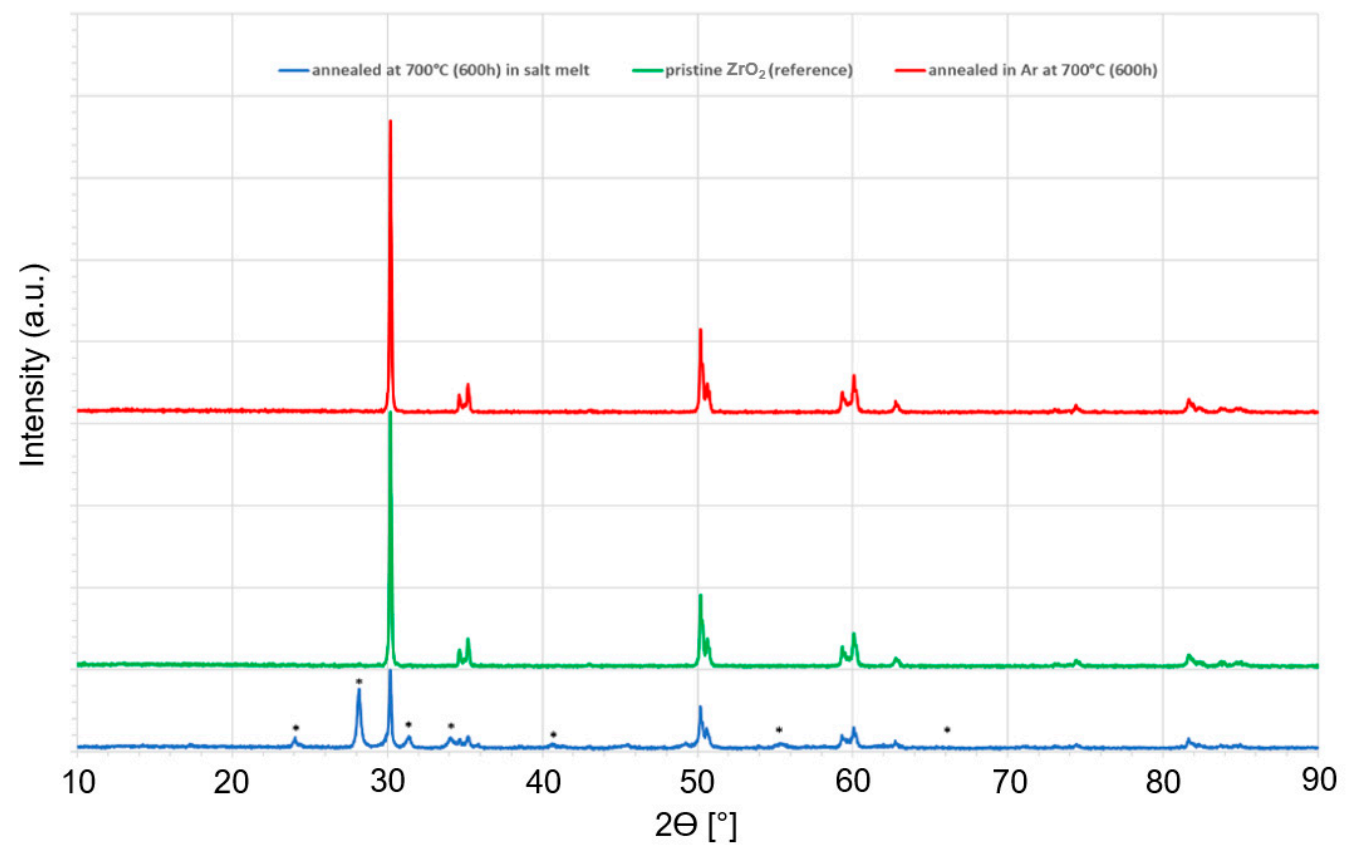

Figure 4. XRD analysis of 3D-printed $\mathrm{ZrO}_{2}$ in three states: annealed at $700{ }^{\circ} \mathrm{C}(600 \mathrm{~h})$ in salt melt, pristine $\mathrm{ZrO}_{2}$ serving as reference and annealed in Ar at $700{ }^{\circ} \mathrm{C}(600 \mathrm{~h})$. All peaks were assigned to tetragonal tazheranite syn (PDF 01-072-7115), except the ones marked with an asterisk, which were assigned to monoclinic baddeleyite syn (PDF 01-081-1314) for the sample annealed at $700{ }^{\circ} \mathrm{C}(600 \mathrm{~h})$ in salt melt.

According to the phase diagrams of $\mathrm{ZrO}_{2}$ stabilized with $\mathrm{Y}_{2} \mathrm{O}_{3}$ [25] and $\mathrm{MgO}$ [24], in the case of pure $\mathrm{ZrO}_{2}$, at temperatures below $\sim 1200{ }^{\circ} \mathrm{C}$ monoclinic baddeleyite (M) should be thermodynamically stable, and beyond $\sim 1200{ }^{\circ} \mathrm{C}$ tetragonal tazheranite (T) should be thermodynamically stable. There is a high-temperature phase change to cubic phase (C), which is stable beyond $2370{ }^{\circ} \mathrm{C}$. When the $\mathrm{ZrO}_{2}$ is stabilized with 3 mole $\% \mathrm{Y}_{2} \mathrm{O}_{3}$, the theoretical phase change of $\mathrm{M} \leftrightarrow \mathrm{T}$ takes place at a much lower temperature of about $600{ }^{\circ} \mathrm{C}$, which is below the test temperature in this work $\left(700^{\circ} \mathrm{C}\right)$. As shown in the phase diagram of $\mathrm{ZrO}_{2}$ stabilized with $\mathrm{MgO}$ [24], compared to $\mathrm{ZrO}_{2}$ stabilized with $\mathrm{Y}_{2} \mathrm{O}_{3}, \mathrm{ZrO}_{2}$ stabilized with $>1 \% \mathrm{MgO}$ has a much higher temperature $\left(1400^{\circ} \mathrm{C}\right)$ for the theoretical phase change of $\mathrm{M} \leftrightarrow \mathrm{T}$. This implies that $\mathrm{ZrO}_{2}$ stabilized with $\mathrm{MgO}$ has lower stability, that is, a higher trend for the $\mathrm{M} \leftrightarrow \mathrm{T}$ phase change at the test temperature in this work $\left(700{ }^{\circ} \mathrm{C}\right)$. Because the 3PB-strength showed almost no change after the thermal treatment without salt, it is reasonable to assume that the phase of the stabilized $\mathrm{ZrO}_{2}$ would not be changed after exposure in the hot $\mathrm{Ar}$ gas at $700{ }^{\circ} \mathrm{C}$ for several hundred hours. Thus, the transformation of the metastable tazheranite $\mathrm{T}$ phase to the thermodynamically stable baddeleyite $\mathrm{M}$ phase should be attributed to the presence of the molten $\mathrm{MgCl}_{2} / \mathrm{NaCl} / \mathrm{KCl}$ salt-that is, molten salt treatment could have a beneficial effect on the $\mathrm{T} \rightarrow \mathrm{M}$ transformation. It was reported in [11] that the $\mathrm{M} \leftrightarrow \mathrm{T}$ phase change in a 8-9 wt. $\% \mathrm{Y}_{2} \mathrm{O}_{3}$-stabilized $\mathrm{ZrO}_{2}$ coating was not observed after $2000 \mathrm{~h}$ exposure in molten $\mathrm{LiCl}-\mathrm{KCl}-\mathrm{UCl}_{3}(5-6 \mathrm{wt} . \%)$ salt (mainly alkali metal chlorides) at $600{ }^{\circ} \mathrm{C}$ under argon atmosphere. Based on this finding, the aforementioned results from the phase diagrams of $\mathrm{ZrO}_{2}$ stabilized with $\mathrm{Y}_{2} \mathrm{O}_{3}$ and $\mathrm{MgO}$ and the calculated $\Delta \mathrm{G}^{\circ}$ values with FactSage in Equations (1-4), the reaction of the $\mathrm{Y}_{2} \mathrm{O}_{3}$-stabilized $\mathrm{ZrO}_{2}$ with $\mathrm{MgCl}_{2}$ (mainly $\mathrm{Y}_{2} \mathrm{O}_{3}$ and $\mathrm{ZrO}_{2}$ with gaseous $\mathrm{MgCl}_{2}$ ) may be the main reason for the $\mathrm{T} \rightarrow \mathrm{M}$ transformation. The experimental measurements showed that the vapor pressure of $\mathrm{MgCl}_{2} / \mathrm{NaCl} / \mathrm{KCl}(38.2 / 41.3 / 20.5$ mole $\%)$ was about $3.5 \mathrm{kPa}$ at $725^{\circ} \mathrm{C}$ [26]. Moreover, in the SEM-EDX images of the molten salt exposed $\mathrm{ZrO}_{2}$ in next subsection, reduced concentrations of the $\mathrm{Y}$ and $\mathrm{Zr}$ elements were observed in a severalmicron-thick layer close to the surface. However, the Mg element on the surface layer of 
the molten salt exposed $\mathrm{ZrO}_{2}$ was not detected, which may be due to the detection limit of EDX (generally $>5$ mole\%). Thus, the detailed mechanism of the molten salt treatment on ceramics is highly suggested to be investigated using other material analysis techniques with a lower detection limit in future work for possible technical applications.

$$
\begin{gathered}
\mathrm{ZrO}_{2}(\mathrm{~s})+2 \mathrm{MgCl}_{2}(\mathrm{~g}) \leftrightarrow \mathrm{ZrCl}_{4}(\mathrm{~g})+2 \mathrm{MgO}(\mathrm{s}) \Delta \mathrm{G}^{\circ}=-16 \mathrm{~kJ} / \mathrm{mole}\left(700^{\circ} \mathrm{C}\right) \\
\mathrm{ZrO}_{2}(\mathrm{~s})+2 \mathrm{MgCl}_{2}(\mathrm{l}) \leftrightarrow \mathrm{ZrCl}_{4}(\mathrm{~g})+2 \mathrm{MgO}(\mathrm{s}) \Delta \mathrm{G}^{\circ}=+133 \mathrm{~kJ} / \mathrm{mole}\left(70{ }^{\circ} \mathrm{C}\right) \\
\mathrm{Y}_{2} \mathrm{O}_{3}(\mathrm{~s})+3 \mathrm{MgCl}_{2}(\mathrm{~g}) \leftrightarrow 2 \mathrm{YCl}_{3}(\mathrm{l})+3 \mathrm{MgO}(\mathrm{s}) \Delta \mathrm{G}^{\circ}=-127 \mathrm{~kJ} / \mathrm{mole}\left(700{ }^{\circ} \mathrm{C}\right) \\
\mathrm{Y}_{2} \mathrm{O}_{3}(\mathrm{~s})+3 \mathrm{MgCl}_{2}(\mathrm{l}) \leftrightarrow 2 \mathrm{YCl}_{3}(\mathrm{l})+3 \mathrm{MgO}(\mathrm{s}) \Delta \mathrm{G}^{\circ}=+97 \mathrm{~kJ} / \mathrm{mole}\left(700^{\circ} \mathrm{C}\right)
\end{gathered}
$$

\subsubsection{SEM-EDX Analysis}

Since no change of the 3PB strength was observed, all the samples of $\mathrm{Al}_{2} \mathrm{O}_{3}$, as well as the samples of $\mathrm{ZrO}_{2}$ after exposure without salt were not analyzed with SEM-EDX. To identify changes of the $\mathrm{ZrO}_{2}$ sample after molten salt exposure, the microstructures of the $\mathrm{ZrO}_{2}$ samples were analyzed before and after molten salt exposure, as well as after pure heat treatment in Ar via SEM and EDX on cross sections. The SEM analysis in Figure 5 gave insights into the material construction before exposure in molten salt and after pure heat treatment in Ar. It was shown that the microstructure of the $\mathrm{ZrO}_{2}$ sample was not changed after pure heat treatment in Ar. On the surface of the samples, the layer formation of the 3D printing was partially visible (the top layer did not cover the entire surface). However, the inner sample showed no cavities, irregularities or defaults. The edge area also gave insight into the grain structure. Grain boundaries were not interrupted by cavities and formed a unified solid material. The grain size was about $\sim 600 \mathrm{~nm}$, with a spherical shape.

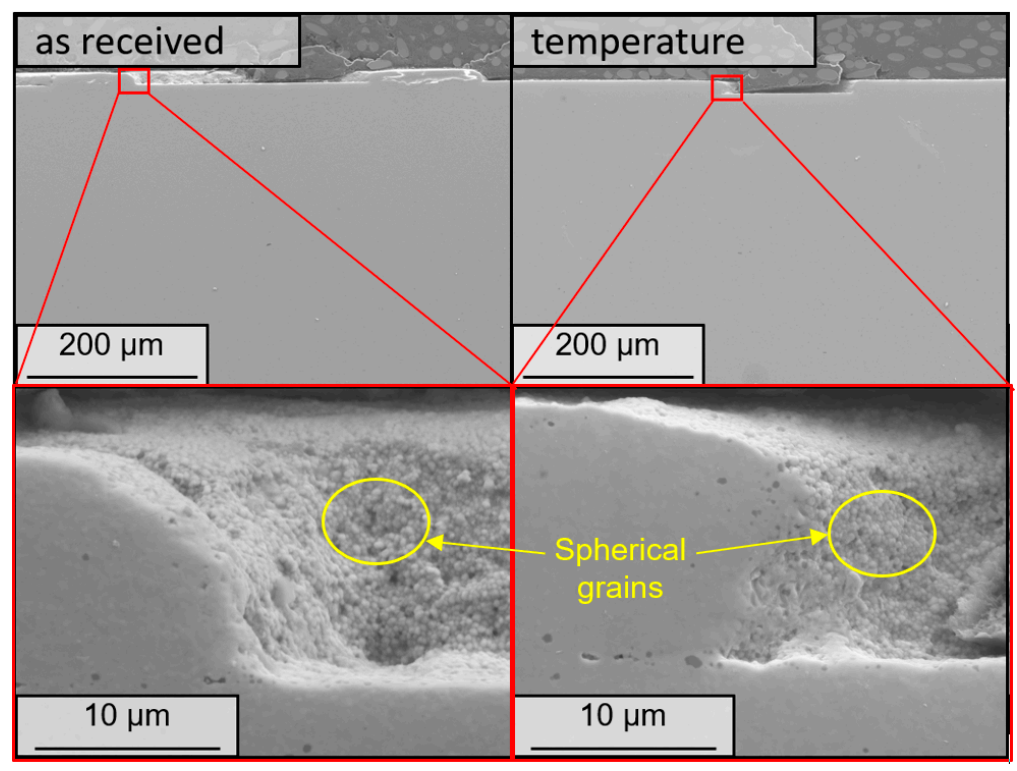

Figure 5. SEM images of the cross section of $\mathrm{ZrO}_{2}$ samples before molten salt exposure (as received) and after pure heat treatment in hot Ar (temperature).

After exposure in molten salt at $700{ }^{\circ} \mathrm{C}$ the $\mathrm{ZrO}_{2}$ samples were again analyzed. The SEM image shows no significant change throughout the material (Figure 6), whereas an obvious change in the grain shape can be observed in the surface area. The grains on the surface were transformed from round to a more angular/crystalline shape. This observation agrees with the results of the XRD analysis in Section 3.2.1, which suggested that a phase change of $\mathrm{T} \rightarrow \mathrm{M}$ occurred at $700{ }^{\circ} \mathrm{C}$. Besides the phase change, the shape change of the $\mathrm{ZrO}_{2}$ grains in the surface area could be another reason for the enhancement of the mechanical strength observed in the mechanical tests. 


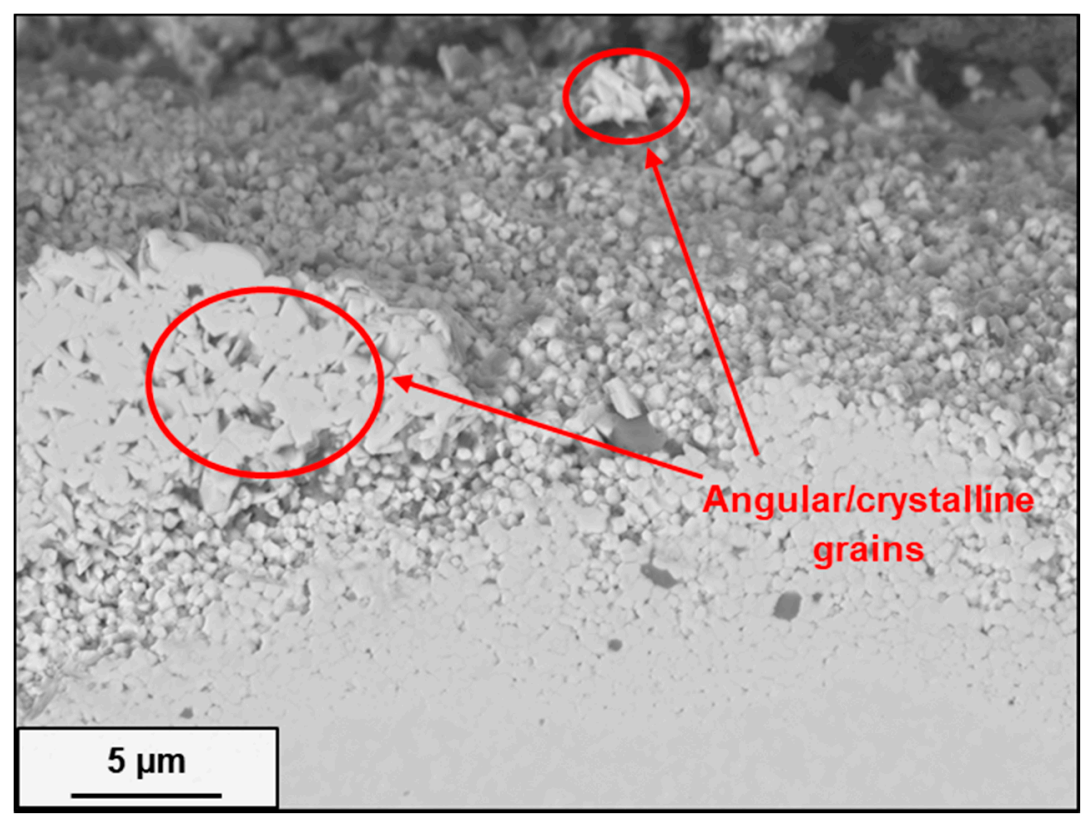

Figure 6. SEM images of the cross section of $\mathrm{ZrO}_{2}$ sample after molten salt exposure.

EDX analysis was used to investigate corrosion penetration. The EDX images, such as $\mathrm{Cl}, \mathrm{Na}, \mathrm{K}, \mathrm{Mg}, \mathrm{Y}$ and $\mathrm{Zr}$ in Figure 7, show that no residual salt elements were detectable in the substrate of the 3D-printed $\mathrm{ZrO}_{2}$ ceramic after exposure, while the concentrations of the $\mathrm{Y}$ and $\mathrm{Zr}$ elements in a several-micron-thick layer on the surface of $\mathrm{ZrO}_{2}$ sample were reduced, which could be explained with the aforementioned reaction of $\mathrm{Y}_{2} \mathrm{O}_{3}$ and $\mathrm{ZrO}_{2}$ with gaseous $\mathrm{MgCl}_{2}$ in Equations (1) and (3). Only a small amount of salt such as $\mathrm{NaCl}$ and $\mathrm{KCl}$ could be detected on the sample surface. This implies that corrosion of the 3D-printed $\mathrm{ZrO}_{2}$ ceramic in molten $\mathrm{MgCl}_{2} / \mathrm{KCl} / \mathrm{NaCl}$, as metallic alloys $[4,5,7]$ and $\mathrm{C} / \mathrm{C}$ $\mathrm{SiC}$ composite [16] caused by corrosive salt impurities like $\mathrm{MgOHCl}$ [5], does not occur at $700{ }^{\circ} \mathrm{C}$ under Ar atmosphere. This observation is supported by the literature [11,12] and the result of our thermodynamic simulations with the commercial software FactSage, which was used for a corrosion mechanism study of a C/C-SiC composite in our previous work [16], finding that the reactions of $\mathrm{ZrO}_{2}$ and $\mathrm{Y}_{2} \mathrm{O}_{3}$ with $\mathrm{HCl}$ (decomposition product of $\mathrm{MgOHCl}$ at $\left.>555{ }^{\circ} \mathrm{C}[6,27]\right)$ have a positive $\Delta \mathrm{G}^{\circ}$ of $156-182$ and $88-208 \mathrm{~kJ} / \mathrm{mole}$ at 500-900 ${ }^{\circ} \mathrm{C}$, respectively (see Equations (5) and (6)). The thermodynamic simulations with FactSage show that the reactions of $\mathrm{Al}_{2} \mathrm{O}_{3}$ with $\mathrm{HCl}$, gaseous $\mathrm{MgCl}_{2}$ and liquid $\mathrm{MgCl}_{2}$ have positive $\Delta \mathrm{G}^{\circ}$ values of 321-323, 11-78 and 310-231 kJ/mole at 500-900 ${ }^{\circ} \mathrm{C}$, respectively (see Equations (7)-(9)), which implies that $\mathrm{Al}_{2} \mathrm{O}_{3}$ could theoretically also have a good chemical compatibility with the corrosive molten chlorides, supporting the results for $\mathrm{Al}_{2} \mathrm{O}_{3}$ in Section 3.1.

$$
\begin{gathered}
\mathrm{ZrO}_{2}(\mathrm{~s})+4 \mathrm{HCl}(\mathrm{g}) \leftrightarrow \mathrm{ZrCl}_{4}(\mathrm{~g})+2 \mathrm{H}_{2} \mathrm{O}(\mathrm{g}) \Delta \mathrm{G}^{\circ}=+(156-182) \mathrm{kJ} / \mathrm{mole}\left(500-900{ }^{\circ} \mathrm{C}\right) \\
\mathrm{Y}_{2} \mathrm{O}_{3}(\mathrm{~s})+6 \mathrm{HCl}(\mathrm{g}) \leftrightarrow 2 \mathrm{YCl}_{3}(\mathrm{l})+3 \mathrm{H}_{2} \mathrm{O}(\mathrm{g}) \Delta \mathrm{G}^{\circ}=+(88-208) \mathrm{kJ} / \mathrm{mole}\left(500-900{ }^{\circ} \mathrm{C}\right) \\
\mathrm{Al}_{2} \mathrm{O}_{3}(\mathrm{~s})+6 \mathrm{HCl}(\mathrm{g}) \leftrightarrow 2 \mathrm{AlCl}_{3}(\mathrm{~g})+3 \mathrm{H}_{2} \mathrm{O}(\mathrm{g}) \Delta \mathrm{G}^{\circ}=+(321-323) \mathrm{kJ} / \mathrm{mole}\left(500-900{ }^{\circ} \mathrm{C}\right) \\
\mathrm{Al}_{2} \mathrm{O}_{3}(\mathrm{~s})+3 \mathrm{MgCl}_{2}(\mathrm{~g}) \leftrightarrow 2 \mathrm{AlCl}_{3}(\mathrm{~g})+3 \mathrm{MgO}(\mathrm{g}) \Delta \mathrm{G}^{\circ}=+(11-78) \mathrm{kJ} / \mathrm{mole}\left(500-900{ }^{\circ} \mathrm{C}\right) \\
\mathrm{Al}_{2} \mathrm{O}_{3}(\mathrm{~s})+3 \mathrm{MgCl}_{2}(\mathrm{l}) \leftrightarrow 2 \mathrm{AlCl}_{3}(\mathrm{~g})+3 \mathrm{MgO}(\mathrm{g}) \Delta \mathrm{G}^{\circ}=+(310-231) \mathrm{kJ} / \mathrm{mole}\left(500-900{ }^{\circ} \mathrm{C}\right)
\end{gathered}
$$



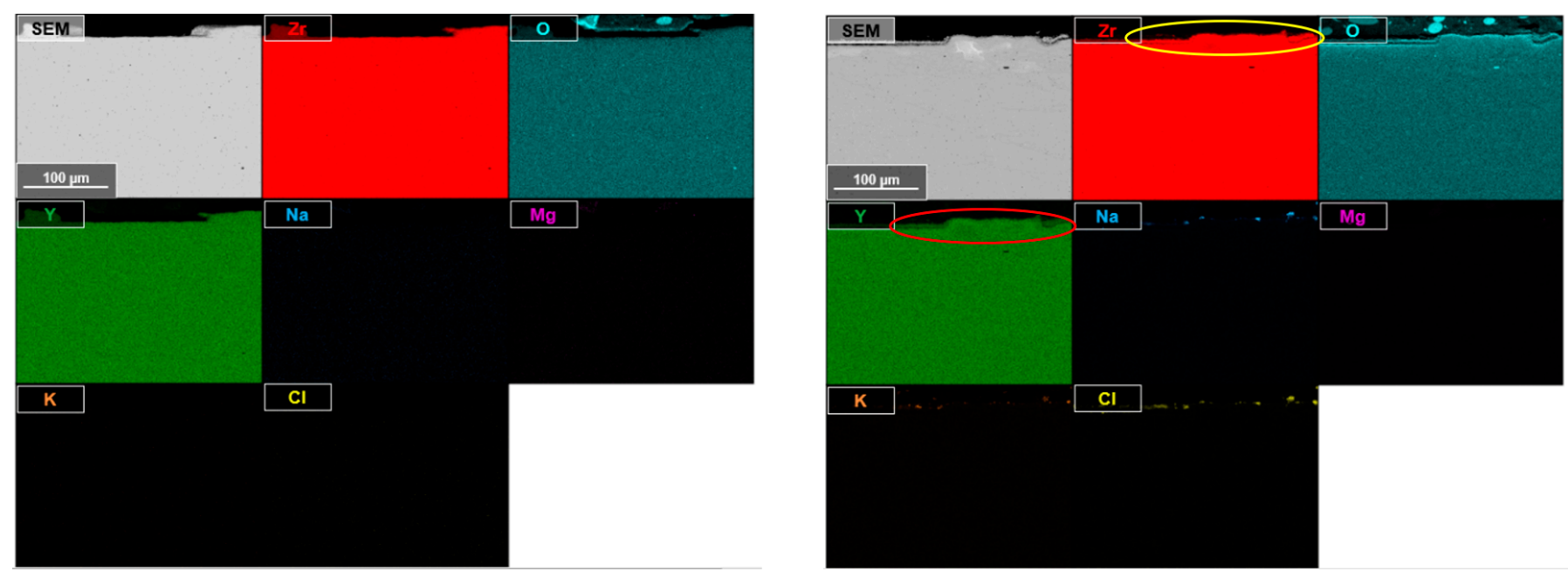

Figure 7. SEM-EDX images of the cross section of $\mathrm{ZrO}_{2}$ samples before (left) and after (right) molten salt exposure. After molten salt exposure, the concentrations of the $\mathrm{Y}$ and $\mathrm{Zr}$ elements on the surface of $\mathrm{ZrO}_{2}$ sample (in red and yellow circles) were reduced.

\section{Conclusions}

The compatibility of 3D-printed $\mathrm{ZrO}_{2}$ and $\mathrm{Al}_{2} \mathrm{O}_{3}$ ceramics with molten chloride salt $\left(\mathrm{MgCl}_{2} / \mathrm{NaCl} / \mathrm{KCl} 60 / 20 / 20\right.$ mole\%) was investigated with immersion tests at $700{ }^{\circ} \mathrm{C}$ for $600 \mathrm{~h}$ under argon atmosphere. The $3 \mathrm{~PB}$ tests and analysis via XRD and SEM-EDX were used to study the change of their mechanical properties, crystal phase and microstructure. The main conclusions of this work are:

- The 3D-printed oxide ceramics $\left(\mathrm{ZrO}_{2}, \mathrm{Al}_{2} \mathrm{O}_{3}\right)$ showed good compatibility in molten chlorides (i.e., corrosion resistance in molten chlorides).

- 3D-printed $\mathrm{Al}_{2} \mathrm{O}_{3}$ maintained its mechanical properties after exposure in the strongly corrosive molten chloride salt. At $700{ }^{\circ} \mathrm{C}$ for $600 \mathrm{~h}$, no indication of reaction or phase change (XRD) between the molten chloride salt and the 3D-printed $\mathrm{Al}_{2} \mathrm{O}_{3}$ was observed.

- Mechanical tests showed that the 3D-printed $\mathrm{ZrO}_{2}$ had enhanced mechanical stability after exposure in molten chlorides. Material tests (XRD and SEM-EDX) showed that the 3D-printed $\mathrm{ZrO}_{2}$ on the surface changed its crystal structure and shape after exposure in the molten chloride salt due to $\mathrm{T} \rightarrow \mathrm{M}$ phase transformation, which may be the reason for the enhanced mechanical properties.

- The exposure tests of the 3D-printed ceramics in Ar without molten salt at $700{ }^{\circ} \mathrm{C}$ for $600 \mathrm{~h}$ showed no mechanical strength changes. Thus, the change of $\mathrm{ZrO}_{2}$ crystal structure and shape is attributed to the molten chloride salt investigated in this work. The thermodynamic calculation shows that the reactions of the $\mathrm{Y}_{2} \mathrm{O}_{3}$ and $\mathrm{ZrO}_{2}$ with gaseous $\mathrm{MgCl}_{2}$ could be the main reason for the phase transformation.

Author Contributions: Conceptualization, W.D., Y.S. and M.B.; methodology, W.D. and Y.S.; validation, W.D., Y.S., M.B., F.K. and M.F.; writing-original draft preparation, W.D., Y.S., F.K. and M.B.; writing-review and editing, M.F., A.B. and T.B.; supervision, T.B.; project administration, W.D. and Y.S.; funding acquisition, T.B. All authors have read and agreed to the published version of the manuscript.

Funding: This research was performed with funding from the German Federal Ministry for Economic Affairs and Energy (BMWi).

Institutional Review Board Statement: Not applicable.

Informed Consent Statement: Not applicable. 
Data Availability Statement: The data presented in this study are available on request from the corresponding authors.

Acknowledgments: The authors would like to thank Alfons Weisenburger at Karlsruhe Institute of Technology (KIT), Germany for discussion and Daniel Cepli at DLR-Institute of Structures and Design for his support.

Conflicts of Interest: The authors declare no conflict of interest.

\section{References}

1. Mehos, M.; Turchi, C.; Vidal, J.; Wagner, M.; Ma, Z.; Ho, C.; Kolb, W.; Andraka, C.; Kruizenga, A. Concentrating Solar Power Gen3 Demonstration Roadmap (Technical Report: NREL/TP-5500-67464); National Renewable Energy Laboratory: Golden, CO, USA, 2017.

2. Guo, L.; Liu, Q.; Yin, H.; Pana, T.J.; Tang, Z. Excellent corrosion resistance of 316 stainless steel in purified $\mathrm{NaCl}^{-\mathrm{MgCl}_{2}}$ eutectic salt at high temperature. Corr. Sci. 2020, 166, 108473. [CrossRef]

3. Sun, H.; Zhang, P.; Wang, J. Effects of alloying elements on the corrosion behavior of Ni-based alloys in molten $\mathrm{NaCl}-\mathrm{KCl}_{-} \mathrm{MgCl} 2$ salt at different temperatures. Corr. Sci. 2018, 143, 187-199. [CrossRef]

4. Grégoire, B.; Oskay, C.; Meißner, T.M.; Galetz, M.C. Corrosion mechanisms of ferritic-martensitic P91 steel and Inconel 600 nickel-based alloy in molten chlorides. Part II: NaCl-KCl-MgCl 2 ternary system. Sol. Energy Mater. Sol. Cells 2020, $216,110675$. [CrossRef]

5. Ding, W.; Shi, H.; Xiu, Y.; Bonk, A.; Weisenburger, A.; Jianu, A.; Bauer, T. Hot corrosion behavior of commercial alloys in thermal energy storage material of molten $\mathrm{MgCl}_{2} / \mathrm{KCl} / \mathrm{NaCl}$ under inert atmosphere. Sol. Energy Mater. Sol. Cells 2018, 184, 22-30. [CrossRef]

6. Ding, W.; Bonk, A.; Bauer, T. Corrosion behavior of metallic alloys in molten chloride salts for thermal energy storage in concentrated solar power plants-A review. Front. Chem. Sci. Eng. 2018, 12, 564-576. [CrossRef]

7. Zhao, Y.; Klammer, N.; Vidal, J. Purification strategy and effect of impurities on corrosivity of dehydrated carnallite for thermal solar applications. RSC Adv. 2019, 9, 41664-41671. [CrossRef]

8. Schulte-Fischedick, J.; Dreißigacker, V.; Tamme, R. An innovative ceramic high temperature plate-fin heat exchanger for EFCC processes. Appl. Therm. Eng. 2007, 27, 1285-1294. [CrossRef]

9. Van Loo, K.; Lapauw, T.; Ozalp, N.; Ström, E.; Lambrinou, K.; Vleugels, J. Compatibility of SiC- and MAX phase based ceramics with a $\mathrm{KNO}_{3}-\mathrm{NaNO}_{3}$ molten solar salt. Sol. Energy Mater. Sol. Cells 2019, 195, 228-240. [CrossRef]

10. Olson, L.C.; Fuentes, R.E.; Martinez-Rodrigueza, M.J.; Ambrosek, J.W.; Sridharan, K.; Anderson, M.H.; Garcia-Diaz, B.L.; Gray, J.; Allen, T. Impact of corrosion test container material in molten fluorides. J. Sol. Energy Eng. 2015, 137, 061007. [CrossRef]

11. Jagadeeswara Rao, C.; Venkatesh, P.; Prabhakara Reddy, B.; Ningshen, S.; Mallika, C.; Kamachi Mudali, U. Corrosion behavior of Yttria-stabilized Zirconia-coated 9Cr-1Mo steel in molten $\mathrm{UCl}_{3}-\mathrm{LiCl}-\mathrm{KCl}$ salt. J. Therm. Spray Tech. 2017, 26, 569-580. [CrossRef]

12. Ravi Shankar, A.; Kamachi Mudali, U.; Sole, R.; Khatak, H.S.; Raj, B. Plasma-sprayed yttria-stabilized zirconia coatings on type 316L stainless steel for pyrochemical reprocessing plant. J. Nucl. Mater. 2008, 372, 226-232. [CrossRef]

13. Vidal, J.; Klammer, N. Molten Chloride technology pathway to meet the U.S. DOE SunShot initiative with Gen3 CSP. AIP Conf. Proc. 2019, 2126, 080006 .

14. He, X.; Robb, K.R.; Sulejmanovic, D.; Keiser, J.R.; Qu, J. Effects of particle size and concentration of magnesium oxide on the lubricating performance of a chloride molten salt for concentrating solar power. ACS Sustain. Chem. Eng. 2021, in press. [CrossRef]

15. Chen, Z.; Li, Z.; Li, J.; Liu, C.; Lao, C.; Fu, Y.; Liu, C.; Li, Y.; Wang, P.; He, Y. 3D printing of ceramics: A review. J. Eur. Ceram. Soc. 2019, 39, 661-687. [CrossRef]

16. Ding, W.; Shi, Y.; Kessel, F.; Koch, D.; Bauer, T. Characterization of corrosion resistance of C/C-SiC composite in molten chloride mixture $\mathrm{MgCl}_{2} / \mathrm{NaCl} / \mathrm{KCl}$ at $700{ }^{\circ} \mathrm{C}$. NPJ Mater. Degrad. 2019, 3, 1-9. [CrossRef]

17. Scheithauer, U.; Schwarzer, E.; Moritz, T.; Michaelis, A. Additive Manufacturing of Ceramic Heat Exchanger: Opportunities and Limits of the Lithography-Based Ceramic Manufacturing (LCM). J. Mater. Eng. Perform. 2018, 27, 14-20. [CrossRef]

18. Liang, Z.Y.; Tang, B.; Gui, Y.; Zhao, Q.X. Corrosion resistance of 3D-printed and cold-rolled titanium alloys at $600{ }^{\circ} \mathrm{C}$ in air and air-SO2 environments, Mater. Today Commun. 2020, 24, 101055.

19. LITHOZ, LCM Technology Material Overview. Available online: https://www.lithoz.com/application/files/2315/5197/6789/2 019_1_Materialfolder_EN_Print-1.pdf (accessed on 7 October 2020).

20. DIN EN 843-1: 2008-08 Beuth.de: Advanced Technical Ceramics-Mechanical Properties of Monolithic Ceramics at Room Temperature-Part 1: Determination of Flexural Strength; Deutsches Institut fur Normung E.V. (DIN): Berlin, Germany, 2008.

21. Ding, W.; Shi, H.; Xiu, Y.; Bonk, A.; Weisenburger, A.; Jianu, A.; Bauer, T. Molten chloride salts for high-temperature thermal energy storage: Mitigation strategies against corrosion of structural materials. Sol. Energy Mater. Sol. Cells 2019, 193, $298-313$. [CrossRef]

22. Gomez-Vidal, J.C.; Fernandez, A.G.; Tirawat, R.; Turchi, C.; Huddleston, W. Corrosion resistance of alumina-forming alloys against molten chlorides for energy production. II: Pre-oxidation treatment and isothermal corrosion tests. Sol. Energy Mater. Sol. Cells 2017, 166, 222-233. [CrossRef] 
23. Mulaudzi, M.G. Ab Initio Study of Structural Stability and Electronic Properties of $\mathrm{ZrO}_{2}-\mathrm{xSx}$ for $0 \leq \mathrm{x} \leq 2$. Ph.D. Thesis, University of Limpopo, Mankweng, South Africa, 2015.

24. Swab, J.J. Role of Oxide Additives in Stabilizing Zirconia for Coating Applications; Report ARL-TR-2591; Army Research Laboratory: Adelphi, MD, USA, 2001.

25. Scott, H.G. Phase relations in the Zirconia-Yttria system. J. Mater. Sci. 1975, 10, 1527-1535. [CrossRef]

26. Wang, X.; Rincon, J.D.; Li, P.; Zhao, Y.; Vidal, J. Thermophysical properties experimentally tested for $\mathrm{NaCl}-\mathrm{KCl}_{-} \mathrm{MgCl}{ }_{2}$ eutectic molten salt as a next-generation high-temperature heat transfer fluids in concentrated solar power systems. ASME J. Sol. Energy Eng. 2021, 143, 041005. [CrossRef]

27. Kipouros, G.J.; Sadoway, D.R. A thermochemical analysis of the production of anhydrous $\mathrm{MgCl}_{2}$. J. Light Met. $2001,1,111-117$. [CrossRef] 